\title{
AL-TA'ASSUF PENGGUNAAN HAK PADA PUTUSAN MAHKAMAH KONSTITUSI NO. 46 TAHUN 2010 TENTANG ANAK LUAR NIKAH
}

\begin{abstract}
Ahmad Arief*
Abstract

Al-Ta'assuf's study is a concept that is very suitable for detecting any form of fraud and the use of personal or group rights. This proof is proven in the analysis of the Constitutional Court Decision, by describing and matching the indicators of al-ta'assuf on the verdict. The results of the evidence state that the Constitutional Court Decision No. 46 is a form of al-ta'assuf, stating the contents of the decision that disguises even the right of the wife and child committed in marriage that is legal and protected by religion and law. The Constitutional Court's verdict is very real contrary to the intention of al-Syā ri 'in every order and prohibition that is maslahat for all.
\end{abstract}

Keywords: al-Ta’assuf, mahkamah konstitusi, pernikahan

\section{A. Pendahuluan}

Risalah Islam yang diturunkan 1400 tahun silam, membawa konsep persamaan hak dan tercantum dalam nas-nas suci Islam. Diajarkan oleh Rasulullah saw. kepada para Sahabatnya, dan diajarkan 
secara turun temurun kepada kaum muslimin setelahnya. Pengakuan Islam tentang hak sangat universal. Kebebasan setiap orang dalam mencari dan menikmati setiap nikmat merupakan sebuah pengakuan yang sangat diakui keberadaan dan posisinya dalam Islam. Kemajemukan hak yang ada pada tiap individu merupakan sebuah keniscayaan, tidak ada seorangpun yang dapat menanggung kewajiban orang lain, atau menzalimi orang lain untuk memenuhi hak pribadinya.

Masyarakat sekuler tidak memiliki landasan metafisik terhadap konsep hak dan kebebasan, konsep kebebasan dan hak dianggap berasal dari pandangan filsafat, yang sulit dipahami kepentingannya. Satu-satunya jalan untuk menerangkan gagasan hak dan kebebasan dengan melihat gagasan tersebut sebagai bagian penting dari suatu sistem politik pemerintahan. Seperti sejarah perjuangan politik dalam periode 'pasca-protestanisme' sejarah Eropa, saat Eropa terpecah belah dalam kerajaan-kerajaan setelah penolakan Paus. Semua kekuasaan kemudian terkonsentrasi secara turun menurun di tangan tokoh-tokoh titular seperti Putra Mahkota. Para tokoh tersebut berkuasa penuh tanpa ada kepemilikan hak selain mereka, contohnya dalam teori yang sempurna seluruh tanah adalah milik raja, tenaga warga dapat digunakan sesuai dengan kepentingannya. Kehendaknya adalah sebuah sumber hukum dan tak seorangpun memiliki hak untuk menentang raja yang lalim. Demikianlah etika politik yang berlangsung tak ada kekuasaanpun bagi warga negara untuk menghadapi kesewenang-wenangan tersebut, karena para 
penguasa tersebut berada di atas hukum. ${ }^{1}$

Ketiadaan sebuah landasan metafisik yang mendasari gagasan kesamaan hak dan kebebasan di Barat Membuat sulit menentukan batasan-batasan gagasan hak dan kebebasan. Kesulitan pun semakin bertambah dalam mengidentifikasi penyalahgunaan, pelanggaran dan kesewenang-wenangan dalam penggunaan hak.

Berbeda dengan Islam, landasan pijakan yang menjadi sumber utama adalah al-Qur'an dan sunah berisi dasar-dasar kewajiban, hak, persamaan dan kebebasan. Selain itu, kedua sumber asasi merangkum batasan-batasan hak dan kewajiban, yang membuat setiap penyalahgunaan, pelanggaran dan kesewenang-wenangan dalam penggunaan hak, harus ditindak sesuai dengan syarak, untuk mewujudkan kemaslahatan bagi manusia.

Pengakuan hak di ranah hukum nasional telah disinggung dalam rumusannya, mulai dari Pembukaan, batang tubuh, maupun penjelasan UUD RI 1945. Hal tersebut dapat dilihat, misalnya, alenia pertama pembukaan UUD RI 1945 "Bahwa Kemerdekaan itu adalah hak segala bangsa dan oleh sebab itu, maka penjajahan di atas dunia harus dihapuskan karena tidak sesuai dengan peri kemanusiaan dan peri keadilan". 2 Pengakuan terhadap "peri kemanusiaan" menjadi

${ }^{1}$ Ṣubhịi 'Abduh Sa‘id, al-Sulțah wa al-Hurriyah fì al-Nizāam al-Islāmī, h. 53 .

${ }^{2}$ Rusjdi Ali Muhammad, Hak Asasi Manusia dalam Perspektif Syariat Islam (Cet. I; Banda Aceh: Ar-Raniry Press, 2004), h. xxiii. 
panduan khusus, yang memberikan hak kemerdekaan bagi setiap pribadi di Indonesia secara khusus.

Pengakuan hak yang dijamin oleh konstitusi Indonesia tidak lantas memberi pengertian, bahwa hak yang ada dapat disalahgunakan untuk kepentingan sendiri secara sadar atau tidak sadar. Penelitian tesis ini dilakukan untuk membuka pandangan penyalahgunaan tadi, memperkenalkan sebuah dasar teori yang telah dipakai oleh para ulama Islam klasik untuk mengenal setiap bentuk penyalahgunaan hak. Sehingga hukum Indonesia dalam penegakan haknya tidak menutup mata terhadap penyalahgunaan bahkan kesewenang-wenangan yang dilakukan dalam penegakannya.

Putusan Mahkamah Konstitusi (MK) No 46 Tahun 2010 yang menetapkan hubungan keperdataan anak di luar nikah kepada ayah dan keluarga ayahnya, juga dilakukan dengan dasar pandangan untuk menegakkan hak anak di luar nikah. Tetapi menjadi sebuah pertanyaan apakah penetapan putusan itu sudah tepat, tidak adakah hak orang lain yang terzalimi dengan adanya putusan tersebut. Dengan kata lain apabila dilakukan analisis dengan analisa hukum dari perspektif manapun putusan tadi mampu menciptakan rasa adil kepada masyarakat.

Berdasarkan uraian latar belakang tersebut, pokok masalah dalam penelitian ini adalah "Bagaimana Analisis al-Ta'assuf dalam Penggunaan Hak Perspektif Hukum Islam tentang Kedudukan Anak Luar Nikah Sesuai Putusan MK No 46 Tahun 2010?”

\section{B. Pembahasan}

\section{Definisi Hak}

Sebagai tatanan hukum, hukum Islam memiliki konsep 
tersendiri dalam menerjemahkan dan menerapkan setiap aturan yang ditetapkannya. Pandangan hukum Islam tentang konsep hak disandarkan dan dikembalikan kepada Allah swt., sebagai pemilik kekuasaan dalam mengatur setiap aturan yang sesuai untuk ciptaannya. ${ }^{3}$

kata آنَ dalam al-Qur'an terdapat dalam banyak ayat dengan makna beragam sesuai dengan rangkaian teks ayat. Hal tersebut terlihat dari beberapa ayat yang mengandung kata آَحْقُ berikut :

a. Al-Haq yang diartikan sebagai ketetapan, kebenaran dan kejujuran. contohnya pada QS Yasin/36: 70.

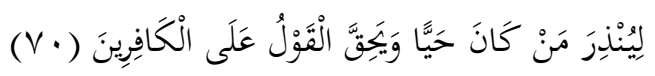

Terjemahnya:

Supaya Dia (Muhammad) memberi peringatan kepada orang-orang yang hidup (hatinya) dan supaya pastilah (ketetapan azab) terhadap orang-orang kafir. ${ }^{4}$

b. Al-Haq diartikan sebagai keyakinan. Sesuai dengan firman

${ }^{3}$ Pernyataan tentang kekuasaan mutlak Allah swt. sebagai al-Syāri telah dijelaskan dalam banyak karya pengantar mempelajari hukum Islam. Dasar hukum Islam adalah Ketuhanan yang berkaitan dengan ketetapan fitrah penciptaan manusia, dengan dasar ketuhanan maka setiap ketetapan dalam setiap perintah dan larangan dibuat untuk memudahkan urusan manusia dari segala belenggu hawa nafsunya. Lihat, Fatḥi al-Duraini, al-Haq wa Madā Sultān al-Daulah fi Taqyidihi (Cet. III; Beirut: Mu'asasah al-Risālah, 1984), h. 16 .

${ }^{4}$ Kementerian Agama RI, Al-Qur'an dan Terjemahnya (Madinah: Majma‘ al-Malik Fahd, 1997), h. 445. 


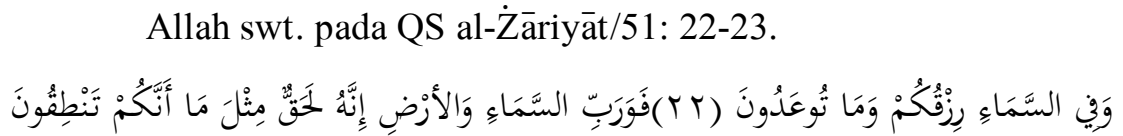

Terjemahnya :

Di langit terdapat (sebab-sebab) rezkimu dan terdapat (pula) apa yang dijanjikan kepadamu. Maka demi Tuhan langit dan bumi, Sesungguhnya yang dijanjikan itu adalah benar-benar (akan terjadi) seperti Perkataan yang kamu ucapkan. $^{5}$

Arti kata hak pada kedua ayat di atas telah mengikat makna hak pada sebuah ketetapan, kebenaran, keyakinan dan keadilan. Makna bahasa yang dipakai dalam firman Allah swt. disesuaikan pula dengan rangkaian kata yang mengikat makna sehingga tujuan penggunaan sebuah kata dapat dipahami dan dimengerti oleh pembaca.

Definisi konsep hak yang mahsyur digunakan sekarang menurut al-Khuli tidak terlepas dari berbagai pendekatan. pendekatan yang digunakan ahli fikih modern dalam mendefinisikan hak seperti pendekatan akar kata, pendekatan hukum positif, pendekatan ahli fikih klasik dan bahkan banyak yang mencoba menggabungkan semua model pendekatan yang ada ${ }^{6}$. Penetapan definisi dengan berbagai sudut telah menjelaskan terjadinya perubahan paradigma konsep hak dari zaman klasik Islam ke modern, atau dengan kata lain menunjukkan kompleksitas hubungan yang harus dijaga agar tidak terjadi tumpang tindih.

\footnotetext{
${ }^{5}$ Kementerian Agama RI, Al-Qur'an dan Terjemahnya, h. 522.

${ }^{6}$ Ahmad Mạ̣mūd al-Khūii, Nazariyah al-Haq, h. 41.
} 
Perbedaan perspektif yang terjadi dikalangan ulama kontemporer berujung pada dua hal penting yang ingin diwujudkan dalam penggunaan hak. Kedua hal tersebut adalah maslahat dan keleluasaan pribadi (l) (انْتِصَّاصُ). Al-Khūli menambahkan, bahwa perbedaan dalam memandang kedua pendekatan adalah faktor utama, sehingga memilih definisi yang dibuat Mustafa Ahmad al-Zarqa, sebab mengakomodir dua hal tersebut.

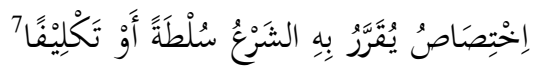

Artinya :

Keleluasaan pribadi yang ditetapkan oleh syariat penguasaannya dan pembebanannya.

Al-Khūli memilih definisi al-Zarqā disertai dengan beberapa catatan penting yaitu penggunaan kata ị̣tisās yang menjadi kata kunci definisi di atas. Kata ihtisās memberikan makna privat kepada pemilik sesuatu dan mencegah penggunaannya dari orang lain. Tetapi keleluasaan pribadi yang diberikan bukanlah sebuah ketetapan yang mudah didapatkan dengan serampangan tetapi didasari oleh ketetapan syariat sebagai sumber ketetapan dalam Islam.

Definisi al-Zarqā memberikan pemahaman dalam menggambarkan tujuan yang ingin diwujudkan melalui istilah hak dalam Islam. Penjelasan definisinya mencakup bahwa hak dalam Islam adalah sesuatu yang dilindungi dan diakui selama masih berada di

\footnotetext{
${ }^{7}$ Ahmad Mạ̣mūd al-Khūli, Nazariyah al-Haq, h. 48.
} 
dalam koridor syariat. Apabila maksud yang diinginkan dalam pemenuhan hak melanggar etika-etika syariat maka syariat secara langsung memberikan pelarangannya secara langsung. Kedua pendekatan yang digunakan konsep hak dalam Islam merupakan gambaran kesempurnaan dan kesesuaian aturan syariat Islam dengan zaman dan tempat penerapannya.

\section{Teori al-Ta'assuf dalam Penggunaan Hak}

Kajian konsep al-ta'assuf baru dibahas secara khusus sebagai bagian pembahasan dalam uṣül al-fiqh kontemporer, tetapi keadaan ini tidak berarti bahwa konsep al-ta'assuf dalam penggunaan hak merupakan hal yang baru diperkenalkan dalam Islam dan tatanan syariatnya. Kajian-kajian ulama klasik seperti al-Ṭuruq al-Hukmiyah oleh Ibnu Qayyim al-Jauziyah dengan menggunakan sinonim kata alta'assuf yaitu al-Muḍārrah fì al-Huqūq. Kitab al-Muwāfaqāt karya Imam Abū Ishāq al-Syātịīi juga menggunakan kata al-Isti'māl alMażmüm yang sinonim dengan kata al-ta'assuf pada zaman sekarang.

Karya kontemporer yang secara khusus membahas konsep alta 'assuf penggunaan hak, adalah buku Nazariyah al-Ta'assuf fí Isti 'māl al-Haq fỉ al-Fiqh al-Islāmì karya Fatḥi al-Durainì, karya tersebut membahas secara khusus dan detail tentang konsep al-ta'assuf penggunaan hak dalam Islam dan beberapa perbandingan dengan konsep al-ta'assuf dalam hukum positif.

Kata ta'assuf (تَعَُُْْ) merupakan bentuk masdar dari kata 
'assafa (عَسَّفَ), 'assafa adalah bentuk fi'il muta'addi dari 'asafa, ${ }^{8}$ keterkaitan bentuk fi'il dan perubahannya memberikan kekayaan makna. Term ta'assuf secara etimologi bermakna menyelewengkan. Apabila disandarkan dengan seseorang sebagai pelaku ta'assuf maka maknanya adalah kezaliman. Bila disandarkan dengan perkataan maka maknanya adalah mengikuti sebuah perkataan tanpa petunjuk atau menerjemahkan sebuah kata dengan makna yang berbeda secara nyata. $^{9}$

Pengertian ta'assuf dalam penggunaan hak yang dimaksudkan adalah suatu pertentangan antara keinginan al-Syāri ${ }^{\circ}$ dengan perbuatan yang secara asal dibolehkan oleh syariat, dan berdampak pada kerugian pihak tertentu atau seluruh manusia secara umum.

Setelah analisa kata perkata al-ta'assuf dalam penggunaan hak, pengertian al-ta'assuf dalam penggunaan hak sebagai sebuah istilah adalah :

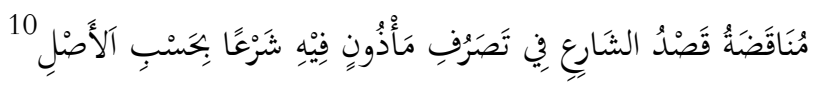

Artinya :

Pertentangan keinginan dengan al-Syāri ' pada Perbuatan yang

${ }^{8}$ Fr. Louis Ma'luf al-Yassu'i dan Fr. Bernard Tottel al-Yassu'i, alMunjid fì al-Lugah wa al-'Alām (Cet. 37; Beirut: Dār al-Masyraq, 1998), h. 505.

${ }^{9}$ Fr. Louis Ma'luf al-Yassu'i dan Fr. Bernard Tottel al-Yassu'i, alMunjid fí al-Lugah wa al-'Alām, h. 505.

${ }^{10}$ Fathị al-Durainī, Nazariyah al-Ta'assuf fí Isti 'māl al-Haq (Cet. III; Damaskus: Mu'asasah al-Risālah, 2008), h. 91. 
oleh syariat dibolehkan pada asalnya

Ahli hukum modern juga mengartikan istilah al-Ta'assuf dalam penggunaan hak dengan :

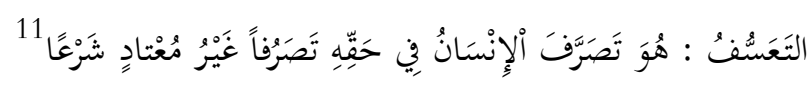

Artinya :

al-Ta'assuf adalah sebuah tindakan yang dilakukan manusia sesuai dengan haknya tetapi tindakan tersebut tidak sesuai secara syariat.

Beberapa ahli hukum barat yang lain juga mengartikan dengan konteks yang berbeda, tetapi maksudnya sama yaitu :

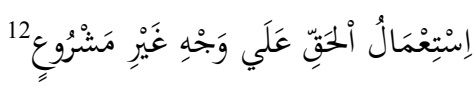

Penggunaan hak pada sesuatu yang tidak dibenarkan secara syariat.

Pemaparan ketiga bentuk pengertian al-ta'assuf dalam penggunaan hak menjelaskan bahwa terjadi perbedaan pandangan dalam menerjemahkan konsep al-ta'assuf dalam penggunaan hak. Perbedaan tersebut sesuai dengan pengertian yang ada, mengacu kepada bentuk tindakan yang digunakan. Pada definisi yang diajukan oleh Fatḥi al-Durainī beliau menjelaskan bahwa tindakan atau perbuatan yang dilakukan adalah sesuai dengan syariat. Definisi kedua dan ketiga menyatakan hal yang sebaliknya bahwa al-ta'assuf adalah penggunaan hak pada tindakan atau perbuatan yang tidak sesuai

${ }^{11}$ Majlis al-a'lā li al-Syu'ūn al-Islamiyah, Kitāb Usbū' al-Fiqh alIslämīi (Kairo: t.p., t.th), h. 110.

${ }^{12}$ Ibid. 
dengan syariat Islam.

Penilaian sebuah perbuatan dalam syariat didasarkan pada jenis-jenis perbuatan yang bisa saja mubah, sunah atau wajib. Setiap jenis perbuatan tersebut mempunyai hukum masing-masing sesuai dengan keadaannya, tetapi yang perlu diketahui setiap perbuatan atau tindakan mempunyai dua al-qasd (maksud) dalam setiap jenis perbuatannya. Kedua al-qasd digambarkan Imam al-Syâtịi sebagai berikut :

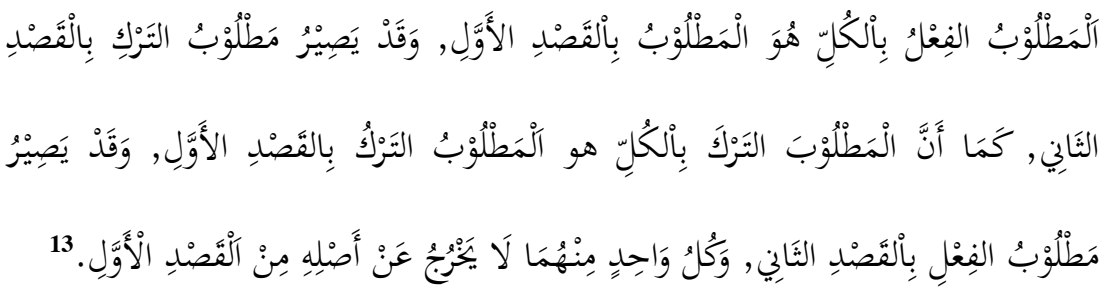

Tuntutan untuk melakukan sesuatu secara utuh merupakan alqașd pertama, tetapi terkadang terjadi transisi menjadi tuntutan untuk meninggalkan yang inilah disebut al-qasd kedua. Sebagaimana tuntutan untuk meninggalkan secara utuh merupakan al-qasd pertama yang terkadang bertransisi pada alqașd kedua yaitu tuntutan untuk melaksanakan. Setiap transisi pada al-qașd kedua tersebut tidaklah kemudian disebut keluar dari tuntutan awal yang diinginkan.

Penjelasan Imam al-Syatibi tentang nilai al-qașd dalam setiap perbuatan memberi kejelasan bahwa teks nas-nas yang ada harus selalu disesuaikan dengan konteks yang berlaku. Sesuatu hal yang telah

${ }^{13} \mathrm{Abu}$ Ishāa al-Syātibī, al-Muwāfaqat fì Ușūl al-Syarì'ah komentar Abdullah Dirrāz, Juz 3(Kairo: Dār al-Ma'rifah, 1997), h. 193. 
menjadi kewajiban dan harus dilaksanakan pada waktu tertentu bisa berlaku rukhsah (keringanan), hal tersebut berlaku pula pada larangan bisa menjadi sebuah kewajiban saat sinyalemen keadaan darurat secara uṣuli terpenuhi. Sedangkan sesuatu yang mubah juga mengandung kedua al-qasd. Al-Qasd pertama mubah adalah perbuatan yang dasarnya sesuai dengan syariat atau sesuai dengan ketentuan syariat sehingga perbuatan tersebut dibolehkan. Tetapi terkadang sebuah perbuatan dibolehkan, serta pelaksanaannya merupakan hak tetapi hasilnya membawa keburukan, kemudaratan bahkan kerusakan, maka hal ini yang dimaksud dengan al-ta'assuf pada definisi pertama.

Definisi kedua dan ketiga memberikan pemahaman yang berbeda dengan definisi pertama, definisi kedua dan ketiga menyatakan yang disebut dengan penggunaan hak pada sesuatu yang dasarnya memang dilarang oleh syariat. Jadi secara syariat perbuatan ini memang telah dilarang, para fuqaha menamakan perbuatan tersebut dengan al-mujāwazah (المجاوزة) atau al-ta'addị (التعدي). Dan perbuatan al-ta'addi atau al-mujāwazah dalam Islam merupakan istilah yang telah paten dipergunakan dalam banyak kasus-kasus fikih.

\section{Analisis al-Ta' assuf dalam Penggunaan Hak pada Putusan No 46}

\section{Tahun 2010}

Posisi anak di luar nikah dengan ditetapkannya putusan MK No 46 Tahun 2010 berubah dari sebelumnya hanya mempunyai hubungan perdata dengan ibu dan keluarga ibunya, ditambahkan dengan ayah dan keluarga ayahnya dengan pembuktian melalui teknologi modern. Meski putusan tersebut telah inkracht van gewisjde karena merupakan putusan MK yang mengadili perkara tingkat pertama dan terakhir. Tetapi putusan merupakan salah satu bentuk 
karya ilmiah yang bisa dianalisis, dikaji bahkan dimentahkan ditangan para peneliti, meskipun tidak akan mempengaruhi ketetapan hukum Mahkamah yang telah menetapkannya.

Putusan Mahkamah Konstitusi dengan penambahan kata "mempunyai hubungan perdata terhadap ayah dan keluarga ayahnya", memancing reaksi yang sangat besar dari para analisis hukum yang ada di Indonesia. Setidaknya terdapat empat artikel media cetak yang peneliti dapatkan yang memuat permasalahan putusan MK, artikel tersebut terbit dalam kurun waktu februari 2012 dengan segala perspektif. Hal yang menarik untuk diungkapkan, bahwa dari keempat artikel tersebut, tiga artikel isinya kurang lebih meminta MK meninjau ulang putusan yang telah dikeluarkan dan satu artikel dengan judul “anak pasti berayah" yang ditulis sendiri oleh Ketua MK saat itu untuk menguatkan putusannya.

Terdapat banyak perspektif yang dapat digunakan dalam melakukan analisis terhadap putusan MK, setiap analisis akan memberi perbedaan pandangan pada perkara. Pada penelitian ini peneliti menggunakan indikator al-ta'assuf dalam penggunaan hak perspektif hukum Islam, dengan memakai indikator tersebut peneliti berharap dapat memberikan gambaran bagaimana Islam memberi respon terhadap setiap hak. Alasan penggunaan indikator al-ta'assuf dalam penelitian ini tidak lepas dari pembahasan tentang hak yang saling berkaitan dalam perkara pengujian undang-undang Perkawinan. Pemohon meminta kepada negara memberikan haknya yang telah dilanggar, khususnya hak anaknya yang dianggap anak di luar nikah, 
dengan kata lain Islam menganggap anak tersebut adalah anak zina. Mahkamah juga dalam hal memberikan keadilan atas dasar haknya yang telah diwakilkan sebagai sebuah lembaga pemerintah, yang mempunyai hak untuk menciptakan rasa adil bagi masyarakatnya.

Meskipun setiap kelompok dari pihak pemohon ataupun MK sebagai pemberi putusan sama-sama memiliki hak. Tetapi perlu diingat bahwa dalam setiap penggunaan hak yang menurut pribadinya atau kelompoknya benar, terkadang hanya mendatangkan kemaslahatan sepihak dan melupakan maslahat pribadi serta kelompok lainnya. Padahal dalam Islam telah diberi penegasan dalam firman Allah swt. di QS al-Ḥujurāt/49: 10.

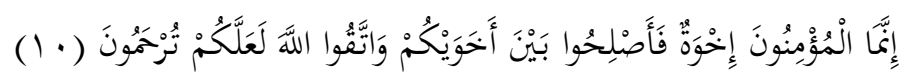

Terjemahnya

Orang-orang beriman itu Sesungguhnya bersaudara. sebab itu damaikanlah (perbaikilah hubungan) antara kedua saudaramu itu dan takutlah terhadap Allah, supaya kamu mendapat rahmat. ${ }^{14}$

Ayat di atas merupakan jaminan mutlak dalam setiap perkataan dan perbuatan seorang mukmin wajib melihat, memandang dan memperhatikan saudara semukminnya. Begitupula dalam menggunakan hak yang dimilikinya setiap muslim wajib pula memperhatikan apakah hak tersebut tidak menimbulkan kemudaratan bagi saudaranya yang lain. Islam tidak memberikan penegasan hanya melalui ayat-ayatnya, tetapi aturan syariat memberi langkah

\footnotetext{
${ }^{14}$ Kementerian Agama RI, Al-Qur'an dan Terjemahnya (Madinah: Majma‘ al-Malik Fahd, 1997), h. 846.
} 
pelaksanaan aturan nas-nas yang ada, sehingga setiap penyalahgunaan dapat dicegah lebih awal sebelum memberi efek kerusakan yang lebih dalam.

a. Pencatatan Nikah dan Walad al-Zinā

Menyamakan istilah anak luar nikah yang ada pada hukum positif Indonesia dengan walad al-zinā, pada hakikatnya membutuhkan pembahasan yang lebih dalam. Hal tersebut terjadi karena ketentuan perundang-undangan tentang perkawinan yang tidak dicatatkan dianggap sebagai perkawinan tidak sah, mengakibatkan semua hak-hak keperdataan yang berkaitan dengan perkawinan tidak didapatkan khususnya pengakuan anak.

Meskipun undang-undang menyatakan seperti itu, tetapi fakta beberapa kalangan di masyarakat dengan masih seringnya terjadi pernikahan tanpa pencatatan, dengan alasan bahwa mereka memenuhi syarat dan rukun nikah dalam Islam sehingga pernikahan mereka telah sah walaupun tanpa pencatatan nikah. Tetapi pernyataan tentang tidak sahnya pernikahan tanpa pencatatan tidak hanya terjadi di Indonesia, terdapat keputusan Nașr Farīd Wāsil ketika menjabat Mufti Mesir yang senada menguatkan. Keputusannya mengatakan bahwa bentuk nikah 'urfí yang dilaksanakan oleh beberapa lembaga pernikahan di Mesir merupakan tindakan batil dan merusak sendi-sendi jiwa dan menyebabkan hilangnya hak anak dan cemohan masyarakat bahkan 
tidak mendapatkan jaminan apapun dari syariat. ${ }^{15}$

Selain itu seorang ulama Mesir Syekh Mutawalli al-Sya'rāwi menegaskan bahwa nikah 'urfí adalah bentuk perbuatan zina karena menyembunyikan pernikahan dan menghilangkan syarat mengumumkan dan menyebarkan pernikahan. ${ }^{16}$

Penjelasan di atas telah menerangkan bahwa secara umum beberapa negara Islam dan para mayoritas ulama Islam telah menegaskan posisi hukum pencatatan pernikahan, dan bahkan menganggap posisi anak yang tidak dicatatkan tidak mendapat pengakuan syariat. Dicantumkan pula dalam penjelasan undangundang perkawinan, bahwa tujuan pencatatan perkawinan yaitu sebagai berikut :

a) Untuk tertib administrasi perkawinan

b) Jaminan memperoleh hak-hak tertentu (memperoleh akta kelahiran, membuat kartu tanda penduduk, membuat kartu keluarga, dan lain-lain)

c) Memberikan perlindungan terhadap status perkawinan

d) Memberikan kepastian terhadap status hukum suami, istri dan anak

e) Memberikan perlindungan terhadap hak-hak sipil yang diakibatkan oleh adanya perkawinan.

Islam telah memberi penegasan yang jelas bahwa bentuk

${ }^{15}$ Fāris Muhammad'Amrān, al-Zawāj al- 'Urfì wa Șuwar ukhrā li alZawāj gair al-Rasmīi (Cet. 1; Kairo: Majmū'ah al-Nil al-'Arabiyah, 2001), h. 51.

${ }^{16}$ Fāris Muhammad'Amrān, al-Zawāj al-'Urfī wa Ṣuwar ukhrā li alZawāj gair al-Rasmīi, h. 54 . 
perkawinan harus mengakomodir semua rukun dan syarat pernikahan yang telah ditetapkan. Improvisasi dalam menerjemahkan dan menerapkan syarat-syarat yang ada merupakan sebuah keniscayaan, hal tersebut tak terlepas dari perkembangan masyarakat. Perlu pula diingat bahwa Islam merestui setiap bentuk perubahan selama tidak bertentangan dengan dasar-dasar syariat, melanggar maqasid al-syariah dan mengakibatkan kerusakan nyata bagi masyarakat Islam sendiri. menilik segala ketentuan yang ada maka pencatatan pernikahan merupakan sebuah langkah improvisasi dalam menjaga ketertiban masyarakat, bahkan menguatkan maksud syariat dalam menjaga manusia dan keturunannya. Tanpa aturan pencatatan pernikahan di masa modern sekarang telah jelas bahwa perlindungan hak-hak kepada suami, istri dan anak sangat sulit diwujudkan.

\section{b. Posisi Walad al-Zinā}

Putusan MK No 46 secara sekilas menurut perspektif hukum Islam telah sangat jelas melanggar beberapa ketentuan dasar yang telah dimuat dalam kasus-kasus fikih klasik. Khususnya dalam permasalahan anak luar nikah yang dalam fikih Islam diistilahkan walad al-zinā, posisi seorang anak luar nikah menurut hukum Islam telah ditegaskan hanya memiliki hubungan perdata dengan ibunya dan keluarga ibunya. Maksud dari kata-kata hubungan perdata dalam undang-undang Perkawinan adalah hak keperdataan seorang anak yang meliputi : perkawinan, perwalian dan warisan. Jadi secara yuridis formal setelah keluarnya putusan MK No 46, anak luar nikah memiliki hubungan perdata kepada ayah dan keluarga ayahnya sama seperti 
anak sah pernikahan.

Islam memasukkan zina dalam jajaran dosa-dosa besar, dasar dari ketetapan tersebut adalah firman Allah swt. pada QS al-Isrā'/17: 32.

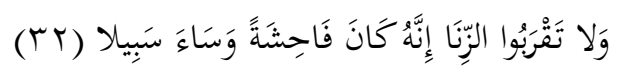

Terjemahnya:

Janganlah kamu mendekati zina; Sesungguhnya zina itu adalah suatu perbuatan yang keji dan suatu jalan yang buruk. ${ }^{17}$

Firman Allah swt. di surah al-Isrā' menggunakan kata lāa taqrabū sebagai bentuk larangan umum. Alasan menggunakan kata tersebut disampaikan oleh Imam al-Nawawi dalam syarh al-Muhazzab, bahwa penyebutan perbuatan zina secara langsung adalah tidak menafikan larangan untuk mendekati. Jadi jikalau menetapkan kata $l_{\bar{a}}$ taznū (janganlah engkau berzina), berarti hanya perbuatan zinanya saja dilarang, adapun hal-hal yang mengantar atau menjadi penyebab awal dari perzinahan masih dibolehkan. Melalui alasan seperti itu al-Syāri' dalam al-Qur'an ingin menjelaskan bahwa janganlah engkau melakukan perbuatan yang mendekat kepada perzinahan, karena mendekati itu akan mengantar pada perzinahan yang sebenarnya. ${ }^{18}$

Kerasnya ketetapan Islam tentang zina juga dikuatkan dengan pemberian bentuk hukuman yang ditentukan ukurannya secara langsung dalam al-Qur'an, yang dikenal dengan istilah hudud sebanyak 100 cambukan bagi pezina laki-laki dan perempuan yang belum

\footnotetext{
${ }^{17}$ Kementerian Agama RI, Al-Qur'an dan Terjemahnya, h. 429.

${ }^{18}$ Muhyì al-Dīn bin Syaraf al-Nawawī, Kitāb al-Majmū' Syarh alMuhażżab, juz 22 (Jeddah: Maktabah al-Irsyād, t.th.), h. 22.
} 
menikah. Sedangkan bagi yang sudah menikah diperberat lagi dengan rajam (ditanam mencapai pinggang lalu dilempari dengan batu), bagi mereka yang sudah menikah. Ketetapan 100 cambukan bagi pria dan wanita yang belum menikah terdapat pada firman Allah swt. Q.S alNur/24: 2.

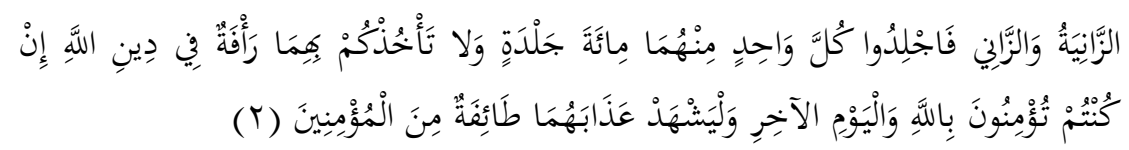

Terjemahnya :

Perempuan yang berzina dan laki-laki yang berzina, maka deralah tiap-tiap seorang dari keduanya serat us kali dera. Dan janganlah belas kasihan kepada keduanya mencegah kamu untuk (menjalankan) agama Allah, jika kamu beriman kepada Allah dan hari akhirat. Dan hendaklah (pelaksanaan) hukuman mereka disaksikan oleh sekumpulan orang-orang yang beriman. ${ }^{19}$

Terhadap hukuman rajam untuk pria dan wanita yang sudah berkeluarga, terdapat beberapa pandangan yang menyatakan tidak ada dasarnya pada al-Qur'an. Padahal apabila kembali pada riwayat dari Rasulullah saw. terdapat riwayat jelas dari Abu Hurairah ra. dan Zaid bin Khālid al-Juhnī. Keduanya berkata: kami bersama Rasulullah saw. kemudian seorang laki-laki berdiri dan berkata: sesungguhnya anakku melakukan zina dengan istriku. Rasulullah saw. berkata: untuk anakmu dicambuk 100 kali dan diasingkan selama setahun sedangkan untuk perempuan apabila dia mengakuinya maka rajamlah. Maka perempuan

\footnotetext{
${ }^{19}$ Kementerian Agama RI, Al-Qur'an dan Terjemahnya, h. 543.
} 
tersebut mengakui dan dirajamlah dia. Riwayat tersebut menjadi pedoman mazhab al-Syafi'i dalam menghukum pria dan wanita yang telah menikah lalu melakukan perbuatan zina. ${ }^{20}$

Beratnya hukuman yang diberikan kepada pelaku zina berbanding lurus dengan efek yang ditimbulkan dari melakukan zina. Berbagai macam persoalan kemasyarakatan telah tercipta diakibatkan bebasnya praktik zina di masyarakat. Efeknya tidak hanya berdampak pada individu, tapi meluas menjadi penyakit masyarakat. Budaya prostitusi misalnya, merupakan lokasi subur penyebaran penyakit yang menyerang imunitas manusia yaitu AIDS, yang hingga saat ini belum ditemukan obat penyembuh untuk para penderita.

Adapun posisi anak yang dilahirkan dari hasil zina dalam hukum Islam memiliki beberapa pengecualian dari anak yang lahir dari hubungan sah suami istri. Khususnya pada permasalahan nasab dan warisan bagi sang anak, ketegasan Islam pada dua permasalahan itu dengan menetapkan bahwa anak zina tidak memiliki sangkut paut apapun kepada laki-laki yang menghamili ibunya dalam pandangan syariat. Dasar dari ketetapan tersebut adalah hadis Rasulullah saw :

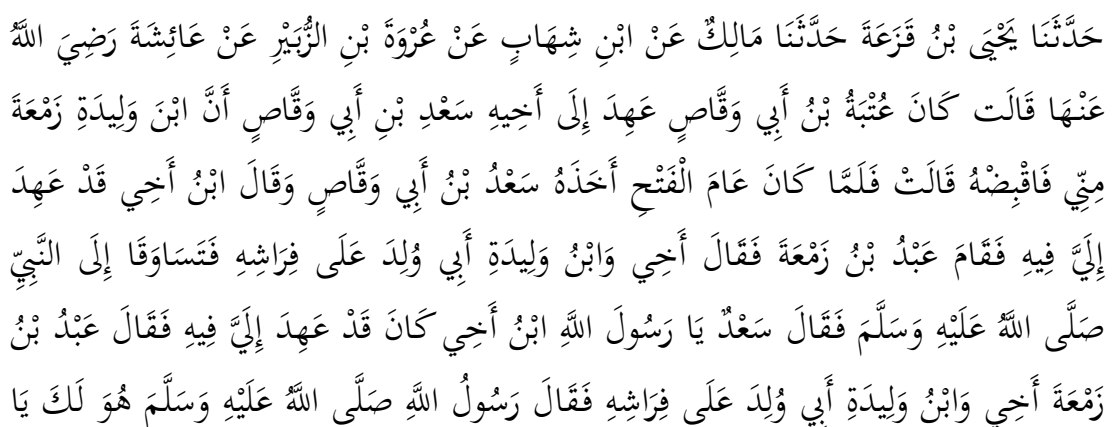

${ }^{20}$ Muhȳi al-Dīn bin Syaraf al-Nawawī, Kitāb al-Majmū‘ Syarh alMuhażżab, h. 26. 


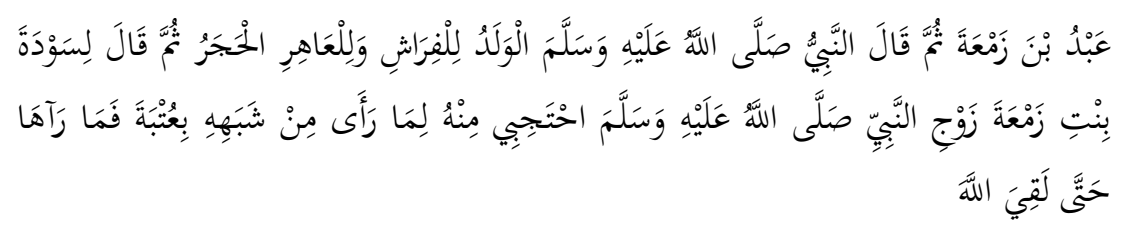

Artinya:

Telah menceritakan kepada kami Yahya bin Qaza'ah, telah menceritakan kepada kami Mālik dari Ibnu Syihāb dari 'Urwah bin al-Zubair dari 'Āisyah ra. berkata; 'Utbah bin Abi Waqash berpesan kepada saudaranya Sa'ad bin Abu Waqash, yang isinya anak laki-laki dari hamba sahaya Zam'ah adalah anakku, maka ambillah. 'A'isyah berkata; Ketika tahun Pembebasan Makkah, Sa'ad bin Abu Waqash mengambilnya, seraya berkata; Itu anak laki-laki saudaraku, yang ia berpesan kepadaku untuk mengambil anak ini. Maka 'Abd bin Zam'ah berdiri lalu berkata: Oh tidak, karena saudaraku dan anak lakilaki hamba sahaya ayahku dilahirkan di tempat tidurnya. Lalu keduanya mengadukan masalah ini kepada Nabi saw. Sa'ad berkata: "Wahai Rasulullah saw., ini adalah anak saudaraku, yang saudaraku telah berpesan kepadaku untuk mengambilnya. Lalu 'Abd bin Zam'ah berkata: "Saudaraku dan anak laki-laki dari hamba sahaya ayahku dilahirkan pada tempat tidurnya". Lantas Rasulullah saw. berkata: "Dia itu milikmu wahai "Abd bin Zam'ah". Kemudian Nabi saw. bersabda: "Anak itu milik pemilik kasur (suami) sedangkan lelaki pezina baginya adalah batu (dirajam)". Kemudian Rasulullah berkata kepada Saudah binti Zam'ah istri Nabi saw.: "Berhijablah engkau daripadanya wahai Saudah, yang demikian karena ada kemiripannya dengan 'Utbah". Maka anak laki-laki dari hamba sahaya Zam'ah itu tidak pernah melihat Saudah selama-lamanya hingga Saudah berjumpa dengan Allah. ${ }^{21}$

Inti dari hadis panjang di atas adalah penggalan sabda

${ }^{21}$ Abū al-Ḥusain Muslim bin al-Hajjāj, Sahịḥ Muslim, Juz 3 (Cet 1: Kairo; Dār al-ḥadis, 1991), h. 1324. 
Rasulullah saw. yang menjadi patokan dasar nasab seorang anak adalah al-firāsy (ranjang). Rasulullah mengiaskan bahwa nasab seorang anak disandarkan kepada pemilik ranjang, makna kata al-firāsy digunakan sebagai bentuk majas dari kata suami. Dalil di atas digunakan oleh ke empat Imam mazhab fikih yaitu Abu Hanifah, Malik, Syafi'i dan Hanbali sebagai landasan penyandaran nasab kepada seorang anak. Dengan ketentuan bahwa hanya suami yang melalui akad sah perkawinan, dan menjadi tempat melekatnya nasab dan semua hubungan keperdataan lainnya. Berdasarkan dalil naqli tersebut juga seorang anak yang merupakan hasil dari hubungan yang tidak diakui oleh syariat hanya disandarkan kepada ibunya.

Ketetapan pemberian hak waris walad al-zinā dari pihak ibu dan keluarga ibu, menjadikan ibu dan keluarga ibu mendapatkan hak waris pula dari walad al-zinā ketika meninggal lebih dulu. Meskipun pada saat meninggalnya walad al-zinā, ayahnya masih hidup tetapi ketiadaan hubungan nasab menjadi hijab bagi bapak untuk mendapatkan warisan dari walad al-zinā.

Besarnya hukuman pelaku zina dan putusnya nasab serta hak waris walad al-zinā dari bapaknya, bukanlah merupakan alasan menjadikan walad al-zinā berada dalam posisi terpinggirkan di mata masyarakat dan syariat. Syariat justru memberikan posisi yang adil dan persamaan pada walad al-zinā dan tidak membenarkan satupun tindakan zalim yang ditujukan kepada walad al-zinā. Islam memberikan penegasan melalui firman Allah swt. Q.S. al-An‘ām/6: 164.

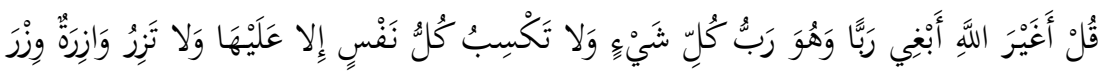




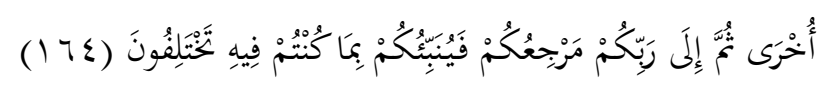

Terjemahnya:

Katakanlah: "Apakah aku akan mencari Tuhan selain Allah, Padahal Dia adalah Tuhan bagi segala sesuatu. Dan tidaklah seorang membuat dosa melainkan kemudaratannya kembali kepada dirinya sendiri; dan seorang yang berdosa tidak akan memikul dosa orang lain. Kemudian kepada Tuhanmulah kamu kembali dan akan diberitakan-Nya kepadamu apa yang kamu perselisihkan." ${ }^{\text {"2 }}$

Ibnu Kasiir dalam tafsirnya menjelaskan bahwa ayat di atas menyatakan, bahwa setiap jiwa diberi balasan sesuai dengan amalnya, apabila orang tersebut berbuat baik maka kebaikan akan menyertainya, sedangkan jika sebaliknya berbuat jahat maka kejahatan adalah balasan baginya. Sesungguhnya tiada seorangpun yang membawa, mewarisi dan bertanggung jawab akan dosa orang lain, oleh karena inilah keadilan pada sisi Allah swt.23

Penegasan ayat 164 surah al-An'ām tadi merupakan sebuah penjelasan posisi walad al-zinā, walad al-zinā tidak mendapatkan balasan apapun dari tindakan jarimah kedua orang tuanya, sebab bagaimana mungkin dia mendapatkan balasan dari tindakan yang dilakukan sebelum kelahirannya. Ketiadaan hubungan nasab kepada bapak bukanlah merupakan penentu baik dan buruknya seseorang,

\footnotetext{
${ }^{22}$ Kementerian Agama RI, Al-Qur'an dan Terjemahnya, h. 217.

${ }^{23} \mathrm{Abu}$ al-Fidā Isma‘îl bin 'Umar Bin Kasīir', Tafsìr al-Qur'an al'Azìm (Cet. 1; Beirut: Dār Ibnu Ḥazm, 2000), h. 743.
} 
karena dalam Islam dan masyarakat Islam meyakini satu-satunya yang menjadi ukuran kelebihan dan kekurangan seseorang di sisi Allah swt. adalah takwa.

Asas maslahat dalam Islam diatur telah diatur sedemikian rupa, dalam setiap bentuk kewajiban, larangan dan pembolehan yang telah ditetapkan oleh al-Syari. Hal tersebut dapat terlihat dalam bentuk hudud cambuk dan rajam dalam zina misalnya, hukuman tersebut secara nyata dapat menghilangkan nyawa pelaku. Tetapi maslahat yang dikandung di dalam hudud zina, adalah menciptakan efek jera dan ancaman nyata bagi setiap individu muslim yang ingin mendekati zina.

Besarnya ancaman pelaku zina sampai mengorbankan jiwa, disebabkan kerusakan yang ditimbulkan dalam masyarakat ketika zina merajalela, jauh lebih dahsyat daripada hukuman zina. Islam juga tidak mengatur setiap jenis hukuman dengan semena-mena, dengan kata lain hanya mengingat kemaslahatan umum tanpa memperhatikan kemaslahatan pribadi. Gambaran nyata dapat diambil dari kisah wanita pezina, yang secara syariat telah jelas hukumannya tetapi ditunda oleh Rasulullah saw. disebabkan adanya maslahat lain yang ada pada diri pelaku, yaitu jiwa anak di dalam kandungan. Apabila bentuk maslahat ada pada setiap bentuk ketetapan syariat dalam Islam tidak terlihat nyata, pada akhirnya segala ketetapan yang ada merupakan ketentuan yang harus diikuti bagi mereka yang beriman kepada Allah swt. dan Rasulullah saw.

\section{Indikator Pembuktian al-Ta'assuf}

Posisi anak luar nikah (walad al-zinā ) menurut ketetapan fikih klasik hanya memiliki hubungan nasab kepada ibunya, ketetapan 
tersebut ditetapkan pula dalam UU RI No 1 Tahun 1974 tentang Perkawinan bahwa "anak luar nikah hanya mempunyai hubungan perdata dengan ibunya dan keluarga ibunya". Ketetapan tersebut menurut pemohon dan MK telah mencedarai hak-hak seorang anak dan mengakibatkan adanya ketidakpastian hukum, karena anak yang dilahirkan tanpa memiliki kejelasan status ayah sering mendapat perlakuan tidak adil. Berdasarkan permohonan pemohon yang dicederai haknya karena berlakunya UU No 1 Tahun 1974, MK menetapkan keadilan yang menjadi haknya sesuai wewenang yang diberikan dengan menambah Pasal 43 UU RI No 1 Tahun 1974. Penggunaan hak yang dilakukan pemohon sebagai individu dan MK sebagai lembaga yang mewakili individu negara dalam Islam sangat diakui. Tetapi perlu diingat penggunaan hak tersebut tidak boleh berujung pada al-ta'assuf, terlebih lagi tidak boleh melawan al-syāri ${ }^{*}$ dengan menghalalkan yang haram dan sebaliknya.

Pembuktian apakah putusan No 46 MK Tahun 2010 tidak melanggar kaidah al-ta'assuf menurut syariat perlu dilakukan, mengingat bahwa Republik Indonesia adalah negara dengan penganut Islam mayoritas, yang secara tidak langsung efek dari putusan akan nyata dampaknya pada masyarakat muslim. Pembuktian al-ta'assuf dilakukan dengan menggunakan setiap indikator yang ada dan diuji pada putusan MK no 46 Tahun 2010. Melalui indikator dan alasanalasan ditetapkannya putusan tersebut akan diuji sejauh mana manfaat dan penyimpangan yang terjadi, agar tidak menghasilkan sebuah keputusan yang ingin mewujudkan keadilan tetapi malah membawa 
mudarat yang lebih banyak.

1) Indikator Intern

Indikator pertama dalam menganalisa adanya al-ta'assuf dengan melihat kondisi intern pemohon dan lembaga MK. Dugaan alta'assuf pada indikator intern dapat dibuktikan dengan melihat dua hal: tujuan yang hanya berorientasi keburukan dan penggunaan hak yang tidak sesuai dengan maslahat syariat. ${ }^{24}$ Apabila pihak pemohon dan MK tidak melanggar dua hal yang terdapat pada indikator pribadi al-ta'assuf, berarti keadilan yang diusung dari Putusan tersebut akan membawa kemaslahatan bersama untuk masyarakat Indonesia.

Analisis yang dilakukan untuk mengungkapkan maksud seseorang, lembaga atau kelompok sangat sulit untuk dilakukan apabila tidak dilakukan dengan bantuan faktor-faktor yang mendasari maksud tersebut.

Faktor pertama dengan melihat maksud tersebut tidak menghasilkan tujuan apapun kecuali mudarat bagi orang lain. Pemohon dalam permohonannya telah mengajukan alasan bahwa pemberlakuan pasal tentang pencatatan perkawinan akan merugikan dan melanggar aturan UUD RI 1945 tentang hak setiap orang untuk membentuk keluarga dan melanjutkan keturunan melalui perkawinan sah. ${ }^{25}$ Faktanya pemohon telah melanggar aturan yang ditetapkan oleh pemerintah dalam melakukan perkawinan dengan seorang laki-laki yang telah beristri, dengan tidak memenuhi prosedur, tata cara dan

${ }^{24}$ Fathị al-Durainī, Nazariyah al-Ta'assuf fí Isti 'māl al-Haq (Cet. III; Damaskus: Mu'asasah al-Risālah, 2008), h. 230, 240.

${ }^{25}$ Mahkamah Konstitusi RI, Putusan MK No 46/PUU-VIII/2010, h. 4. 
persyaratan sebagaimana diatur UU RI No 1 Tahun 1974.26 Alasan tersebut saja telah membuat permohonan pemohon dalam perkara tersebut tidak dapat dilanjutkan karena pemohon sama sekali tidak mempunyai hak untuk mengajukan perkara.

Permohonan pemohon untuk menghapus dua ketentuan yaitu tentang pencatatan dan nasab anak luar nikah merupakan bentuk kemudaratan yang sangat jelas. Jadi pengajuan permohonan yang dilakukan pihak pemohon dari diri pribadi tidak mempunyai tujuan lain selain menimbulkan mudarat bagi kaum muslimin lainnya. Tujuan pencatatan pernikahan adalah langkah tertib administrasi yang dilakukan oleh pemerintah kepada masyarakat dengan tujuan memberikan kepastian status dan perlindungan hak-hak sipil dari perkawinan. Terlebih lagi penyandaran nasab seorang anak yang hubungan pernikahannya tidak jelas kepada bapaknya akan mencederai bahkan menzalimi anak dan istri dari hubungan sah perkawinan.

Lembaga MK sebagai pemutus keadilan dalam perkara pengujian UU Perkawinan, telah menjelaskan dan mengakui dalam pertimbangan hukum yang dibuatnya. Terdapat causal verband (sebab akibat) antara kerugian dimaksud dengan berlakunya undang-undang yang dimohonkan pengujian, sehingga para pemohon memenuhi syarat legal standing permohonan. Tetapi pada poin pendapat mahkamah permohonan Pemohon untuk menghapus pasal 2 UU No 1 Tahun 1974

\footnotetext{
${ }^{26}$ Mahkamah Konstitusi RI, Putusan MK No 46/PUU-VIII/2010, h.15.
} 
dianggap tidak beralasan hukum. Sedangkan permohonan tentang Pasal 43 ayat 1 UU No 1 Tahun 1974 dinyatakan bertentangan dengan UUD 1945.27

Pertimbangan MK yang menyatakan adanya causal verband antara kerugian yang dimaksud dengan berlakunya Pasal 2 ayat (2) dan Pasal 43 ayat (1). Tetapi memutuskan dengan tidak mengabulkan permohonan tentang penghapusan pencatatan dan menyatakan Pasal 43 ayat (1) tentang nasab anak di luar nikah. Seharusnya ketika MK menolak melanjutkan pengujian Pasal 2 ayat (2) berarti menolak pula pengujian Pasal 43 ayat (1) disebabkan kedua pasal tersebut memiliki keterkaitan secara langsung. Mudarat yang terjadi dengan menghapuskan pencatatan perkawinan sebagai langkah penertiban hampir seimbang dengan menyatakan bahwa seorang anak luar nikah memiliki hubungan nasab dengan bapaknya.

Faktor kedua yang digunakan oleh para ulama dalam menilai indikator intern perbuatan al-ta'assuf adalah penggunaan hak yang tidak menghasilkan maslahat yang diinginkan. Imam Malik mencontohkannya seperti pada persoalan wali yang ingin menikahkan putrinya dengan calon suami yang tidak memiliki apapun, jawaban Imam Malik boleh saja tapi cenderung untuk melarangnya dikarenakan mudarat nyata.$^{28}$ Pertimbangan seperti tersebut seharusnya digunakan MK sebagai lembaga negara pelindung konstitusi, yang diberi wewenang untuk menciptakan keadilan bagi masyarakat. sehubungan

\footnotetext{
${ }^{27}$ Mahkamah Konstitusi RI, Putusan MK No 46/PUU-VIII/2010, h. 36.

${ }^{28}$ Mālik bin Anas, al-Mudawanah al-Kubrā, Juz 4 (Kairo: Maṭbu'ah al-Sa‘ādah, $1323 \mathrm{H})$, h. 155.
} 
dengan kewenangan itu MK mempunyai hak untuk menetapkan keadilan yang sesuai dengan agama, norma dan adat yang masih berlaku kental di Indonesia.

Sesuai dengan pertimbangan tersebut putusan MK No 46 Tahun 2010 dalam pandangan syariat telah benar memiliki kemaslahatan dalam penetapannya. Maslahat tersebut beralasan karena penilaian MK yang menyatakan tidak ada perempuan yang hamil tanpa terjadinya pertemuan ovum dan spermatozoa. Menyatakan pula bahwa tidak tepat dan tidak adil manakala hukum menetapkan bahwa anak diluar nikah hanya memiliki hubungan perdata dengan ibunya, lebih tidak adil dan tidak tepat jika hukum membebaskan laki-laki yang melakukan hubungan seksual penyebab kehamilan. ${ }^{29}$ Maslahat yang diinginkan MK adalah perlindungan dan pertanggungjawaban kepada anak dari kedua belah pihak laki-laki dan perempuan. Tetapi MK melupakan satu hal apabila hukum memberi keadilan dengan menyatakan memberikan hubungan perdata kepada ayah, bagaimana keadilan bagi pihak istri dan anak sah. Menjaga hak dan kemaslahatan istri dan anak sah dalam pandangan syariat dan hukum kedudukannya lebih utama daripada penetapan nasab anak luar nikah.

Pandangan tersebut tidak berarti menilai nasab anak luar nikah tidak harus dilindungi, tetapi pertimbangan maslahat yang dimiliki MK telah melanggar batas dari sisi syariat ketika menetapkan

\footnotetext{
${ }^{29}$ Mahkamah Konstitusi RI, Putusan MK No 46/PUU-VIII/2010, h. $34-35$.
} 
persoalan yang menyalahi kemaslahatan umum para istri dan anak yang sah. Melihat kedua faktor yang dilakukan untuk menilai indikator intern tindakan al-ta'assuf dalam penggunaan hak, pemohon dan MK menurut pandangan syariat dapat dilarang untuk menetapkan putusan tersebut menjadi sebuah hukum yang berlaku secara inkracht van geswijde.

2) Indikator Ekstern

Penetapan sebuah tindakan atau perkataan termasuk dalam kategori al-ta'assuf tidak hanya dilihat dari indikator intern yang terdapat dari dalam diri pelaku. Syariat juga dapat memberikan pandangan dan penilaian sebuah perbuatan dari cacat nyata yang timbul dalam menimbang dua kemaslahatan, atau dengan kata lain tidak terdapat kesesuaian antara dua maslahat. Jadi pada indikator ekstern penilaian al-ta'assuf yang ingin diketahui bagaimana pertimbangan antara dua kemaslahatan. Pertimbangan yang digunakan dalam menilai indikator luar ada tiga yaitu :

Cacat yang nyata di antara dua maslahat, yang tidak memungkinkan adanya kesesuaian pada keduanya secara mutlak.

Mudarat umum yang akan menimpa masyarakat Islam, atau golongan tertentu dalam masyarakat disebabkan karena penggunaan hak.

Mudarat yang timbul dari penggunaan hak seseorang atau golongan seimbang dengan maslahat yang timbul, bahkan bisa lebih besar mafsadah dari maslahatnya, meskipun tidak ada kesesuaian antara dua kemaslahatan. ${ }^{30}$

\footnotetext{
${ }^{30}$ Fathịi al-Durainī, Nazariyah al-Ta 'assuf fí Isti 'māl al-Haq, h. 252.
} 
Pertimbangan yang terjadi dari putusan MK adalah pertimbangan antara maslahat anak sah dan maslahat anak luar nikah, apabila kedua maslahat tersebut ditimbang kemudian menghasilkan putusan seperti yang dikehendaki MK, yaitu menyandarkan semua hak keperdataan anak luar nikah kepada pihak laki-laki. Putusan tersebut akan bertentangan dengan dasar-dasar syariat yang digolongkan dalam al-ḍarūiyät ${ }^{31}$, masalah nasab termasuk dalam maqāsid al-syarī 'ah yang harus dijaga dan kemaslahatannya lebih dikedepankan daripada masalah apapun. Putusan MK tidak memberi penjagaan terhadap nasab yang menjadi salah satu poin penting dari al-darūriyāt al-khamsah.

Posisi putusan MK dalam pandangan Syariat dengan jelas telah memenuhi ketiga faktor yang digunakan dalam menilai indikator ekstern al-ta'assuf dalam penggunaan hak. faktor pertama yaitu tidak mungkin menyamakan antara hak anak yang berada dalam status hubungan nikah yang memiliki hak keperdataan penuh, dengan anak di luar nikah atau yang hubungannya pernikahannya masih dipertanyakan. Faktor kedua yaitu kepentingan hak yang ingin dipenuhi akan memberikan mudarat yang nyata kepada masyarakat muslim Indonesia. Sedangkan faktor ketiga mudarat yang akan menimpa dengan pemberian hak perdata tersebut jauh lebih besar

${ }^{31}$ Al-Ḍarüriyāt adalah sesuatu yang harus ada dalam mewujudkan maslahat hidup di dunia dan di akhirat, dan apabila ketetapan tersebut tidak dijaga tidak akan terwujud maslahat apapun di dunia, bahkan membawa kerusakan nyata dan mengakibatkan kerugian. Lihat, Abu Isḥāq al-Syāțibī, alMuwāfaqat fì Ușūl al-Syarī'ah komentar Abdullah Dirrāz, Juz 2 (Kairo: Dār al-Ma'rifah, 1997), h. 8. 
daripada maslahat yang ingin diberikan kepada anak luar nikah.

Kedua indikator yang digunakan untuk mengidentifikasi sebuah tindakan baik berupa perkataan dan perbuatan sebagai alta'assuf dalam penggunaan hak, telah digunakan untuk menganalisis putusan MK No 46 Tahun 2010. Sesuai dengan analisis al-ta'assuf tersebut maka putusan MK seharusnya tidak menyimpulkan ketetapannya dengan memberikan hak perdata kepada anak luar nikah. Sebab penggunaan kata hak perdata akan selalu dipahami dengan hubungan nasab, yang sebagaimana diketahui dalam Islam nasab hanya tercipta dibawah ikatan sah perkawinan.

Kesimpulan hukum yang diputuskan untuk memberi perlindungan kepada anak luar nikah tetapi melupakan hak dan kepentingan anak yang memiliki hubungan status tetap sebagai hasil perkawinan yang sah, merupakan alasan utama mengapa putusan MK tersebut adalah bentuk al-ta'assuf. Penilaian al-ta'assuf terhadap putusan tersebut bukan berarti Islam tidak memberikan hak kepada anak luar nikah. hak anak luar nikah tetap harus diberikan dan dilindungi tetapi tidak dengan mencampuradukkan hubungan nasab yang sah dengan yang tidak sah.

c. Solusi Hukum

Sebuah kritik terhadap sebuah putusan hukum bukanlah merupakan penilaian cacat terhadap putusan hukum tersebut, karena sebuah putusan hukum memiliki ruang dan waktu, apabila ternyata putusan tersebut tidak sesuai untuk zaman sekarang, bukan berarti put usan tersebut tidak berlaku untuk zaman selanjutnya. Ibnu Qayyim al-Jauziyah mengingatkan perubahan ketetapan hukum dipengaruhi oleh perubahan zaman, tempat, keadaan, niat dan tradisi, perubahan 
terjadi karena dasar dari syariat Islam adalah hikmah dan maslahat hamba dalam kehidupan dunia dan akhiratnya.32

Berdasarkan pandangan maslahat tadi putusan MK No 46 Tahun 2010 benar memiliki maslahat dengan memberikan penyandaran hak anak luar nikah kepada ayahnya, tetapi maslahat tersebut hanya nyata bagi pemohon. Padahal hasil keputusan MK sebagaimana kewenangannya merupakan putusan final yang merubah dasar filosofis sebuah pasal, dan akan diajukan ke Presiden dan DPR untuk menyusun sebuah bentuk pasal yang tepat. Tetapi dengan penggunaan kata "hak keperdataan" yang akan menimbulkan makna hak nasab, menjadikan pemberian segala hak keperdataan anak luar nikah terhadap ayahnya merupakan aturan umum yang baru dan berbeda dengan tradisi pemikiran masyarakat.

Pengajuan perkara yang dilakukan oleh pemohon dalam hal ini terjadi kesalahan prosedur, kesalahan prosedur yang mengakibatkan adanya indikasi al-ta'assuf dalam penggunaan hak terjadi, karena pemohon secara pribadi ingin mendapatkan haknya dengan jalan merubah aturan umum yang maslahatnya jauh lebih besar. Permohonan pemohon untuk mendapatkan haknya seharusnya tetap diajukan ke Pengadilan Agama, karena hak yang ingin dicapai adalah kaitannya dengan pernikahan pemohon yang belum memiliki ketetapan hukum yang tepat.

${ }^{32}$ Ibnu al-Qayyim al-Jawziyah, I'lām al-Muwaqi în, Juz 4 (Cet 1; Jeddah: Dār Ibnu al-Jaūzìi, 1423H), h. 337. 
Adapun putusan MK yang menyatakan memberikan hak keperdataan kepada ayah dan anak luar nikah merupakan titik permasalahan yang harus diberi batasan. Al-Ta'assuf pada putusan tersebut terjadi sepanjang dimaknai bahwa hak keperdataan tersebut dimaknai sebagai hubungan nasab. Agar tidak terjadi anggapan seperti itu, maka penggunaan kata hak perdata harus dihindari, misalnya dengan menggantinya dengan kata bertanggung jawab terhadap anak luar nikahnya. Kata bertanggung jawab tersebut ketika digodok DPR, DPR harus memperjelas tanggung jawab tersebut melingkupi tanggung jawab tertentu saja dan tetap tidak memberikan hubungan nasab kepada ayah dan anak luar nikah.

Terdapat pula fatwa Majelis Ulama Indonesia No 11 Tahun 2012 yang merupakan tanggapan atas putusan MK No 46 Tahun 2010. Menyatakan dalam rekomendasinya bahwa pemerintah wajib melindungi anak hasil zina dan mencegah terjadinya penelantaran, terutama dengan memberikan hukuman kepada laki-laki yang menyebabkan kelahiran, dengan hukuman pemenuhan kebutuhan hidup anak.33 Fatwa MUI tersebut senada dengan makna yang diinginkan dari penelitian al-ta'assuf ini. Akan tetapi penetapan MUI masih membatasi makna anak luar nikah hanya terbatas kepada anak hasil perzinahan, padahal jika diteliti lebih dalam bentuk pernikahan tanpa pencatatan yang banyak terjadi di Indonesia, mengakibatkan reduksi terhadap anak juga. Seharusnya MUI harus berani menyatakan bahwa anak-anak hasil pernikahan yang masih diperdebatkan ketetapan pernikahannya, harus diakomodir dalam fatwa tersebut.

${ }^{33}$ Majelis Ulama Indonesia, Fatwa MUI No 11 Tahun 2012 tentang Kedudukan Anak Hasil Zina dan Perlakuan Terhadapnya, h. 10. 
Mengategorikan putusan MK No 46 sebagai sebuah putusan yang mengandung al-ta'assuf, tidak menyatakan bahwa rangkaian proses dan hasil putusannya adalah sebuah pelarangan yang abadi. Perlu diingat bahwa dari definisi yang telah dijelaskan sebelumnya alta'assuf terjadi pada tindakan yang pada asalnya dibolehkan oleh syariat, tetapi kemudian terjadi pertentangan dengan maksud syariat pada proses dan hasil tindakan tersebut. Sebaliknya apabila indikator yang menyebabkan al-ta'assuf dihilangkan maka tindakan tersebut kembali pada sifat asalnya yaitu boleh. Putusan yang dikeluarkan MK juga seperti itu, apabila penyebab putusan tersebut menjadi al-ta'assuf dihilangkan dengan merubah atau menjelaskan lebih rinci maksud dari putusan tersebut, maka pernyataan isi putusan bisa dijalankan untuk mencapai maksud yang diinginkan.

\section{Kesimpulan}

Analisis al-ta'assuf dalam penggunaan hak apabila dikaitkan dengan Putusan MK No 46 Tahun 2010 tentang penyandaran posisi keperdataan seorang anak di luar nikah kepada ayah dan keluarga ayahnya. Membuktikan adanya indikasi besar bahwa Putusan MK adalah sebuah tindakan al-ta'assuf dalam penggunaan haknya. Secara status MK sebagai lembaga pemutus keadilan memiliki hak untuk menciptakan keadilan bagi warga negara Indonesia yang dinaunginya. Tetapi Putusan MK tersebut telah memberikan mudarat yang sangat besar kepada para istri sah yang memiliki anak sah dari hubungan pernikahan yang sah dan dilindungi oleh agama dan hukum. Pemohon pada perkara pengujian undang-undang di MK juga secara asal 
memiliki hak untuk mencari keadilan atas kesewenang-wenangan yang dideritanya. Akan tetapi pengajuan yang dilakukan ke MK, telah menjadikan pengajuan perkaranya adalah bentuk al-ta'assuf penggunaan hak diakibatkan mudarat yang didapatkan oleh anak dari perkawinan sah. Selain analisa tadi, terdapat fatwa MUI yang menentang putusan MK no 46 tersebut. Fatwa tersebut berkesimpulan untuk menegaskan posisi anak zina dengan ayahnya, tetapi MUI memberi saran ke DPR agar memasukkan poin pertanggungjawaban seorang ayah kepada anak zinanya meskipun tanpa hubungan nasab. Meskipun fatwa MUI hanya membatasi pada posisi anak zina, tetapi saran pertanggungjawaban yang diberikan MUI merupakan sebuah solusi untuk keluar dari kondisi al-ta'assuf yang menaungi putusan MK. Selain solusi tadi, putusan MK tersebut tidak akan berimplikasi al-ta'assuf apabila kata "hak keperdataan" diganti dengan kata lain yang tidak memiliki ambiguitas makna, sebab hak keperdataan selalu identik dengan nasab.

\section{Referensi}

'Abdul Khāliq, Farìd. al-Fiqh al-Siyāsī al-Islāmī mabādi' Dustūriyah al-Syūrāa al-'Adl al-Musāwah. Cet. 1; Kairo: Dār al-Syurūq, 1998.

'Abdurraḥman, Abd al-'Aziz. 'Ilm al-Maqāshid al-Syāri'i. Cet I; Riyadh: Maktabah Malik al-Fahd, 2002.

Abu 'Isāa, Muhammad bin 'Isā. Sunan al-Tirmiẓi, Juz 3. Cet 2; Kairo: Maktabah Mustafa, t.th.

Abu al-Fidā, Isma'il bin 'Umar Bin Kasīir'. Tafsir al-Qur'an al-'Azịm. Cet. 1; Beirut: Dār Ibnu Ḥazm, 2000.

Abu Daud, Sulaiman bin al-Asy'aș. Sunan Abi dāud, Juz 3. Beirut: al-

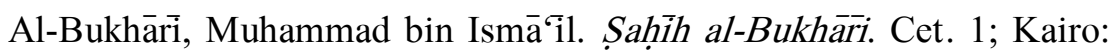


Dār Ibnu Ḥazm, 2008.

Al-Durainī, Fathì. al-Haq wa Madā Sultān al-Daulah fi Taqyidihi. Cet. III; Beirut: Mu'asasah al-Risālah 1984.

. Nazariyah al-Ta'assuf fí Isti 'māl al-Haq. Cet. III; Damaskus: Mu' asasah al-Risālah, 2008.

Al-Fāsì, 'Ilal. Maqāshid al-Syarī'ah wa Makārimuhā. Cet. IV; Dār alGharb, 1993.

Al-Gazali, Abū Ḥāmid Muhammad. al-Mustașfā min 'Ilmi al-Usūl, Juz 1. Madinah: Syirkah Madinah al-Munawwarrah li Țibā'ah, 2008.

Al-Ḥambalȳ, 'Abdurahman bin Rajab. Tafsīi Ibnu Rajab al-Hambalȳ, Juz 1. Cet 1; Riyad: Dār al-'Āṣimah, 2001.

Ali, Achmad. Menguak Teori Hukum dan Teori Peradilan. Cet. 4; Jakarta: Kencana, 2012.

Al-Isnawì. Nihāyah al-Sūl Syarh Minhāj al-Wuṣūl fì 'Ilm al-Uṣūl. Beirut: Dār al-Kutub al-'Ilmiyyah, t.th.

Al-Jawziyah, Ibnu al-Qayyim. I'Tàm al-Muwaqi 'in, Juz 3. Cet 1; Jeddah: Dār Ibnu al-Jaūzì, 1423H.

Al-Kailāni, Abdurraḥmān Ibrāhīm. "Taḥqiq al-Manāt 'Ind al-Ușūliyyīn wa Asaruh fì Ikhtilāf al-Fuqahà". Majallah al-Syarī'ah wa alDirāsāt al-Islāmiyyah 58 (Sebtember, 2004)

Al-Khūii, Ahmad Mahmūd. Nazariyah al-Haq. Cet. II; Kairo: Dār alSalām, 2008.

Al-Zuhaili, Wahbah. Fiqh al-Islämī wa Adillatuh, Juz 8. Cet. 3; Beirut: Dār al-Fikr, 1418 H./1997 M.

. Ușūl al-Fiqh al-Islāmīi, Juz 2. Cet. 14; Damaskus: Dār alFikr, 2005.

Asmawi. Perbandingan Ushul al-Fiqh. Cet. I; Jakarta: Amzah, 2011.

Asshiddiqqie, Jimmly. Konstitusi dan Konstitusionalisme Indonesia. Jakarta: Konstitusi Press, 2005. 
Bek, Khudari. Tarikh al-Tasyri' al-Islami. t.tp; Kairo: Dar al-Fikr, t.th. Byers, Michael. "Abuse of Rights: An Old Principle, A New Age." McGill Law Journal, vol. 47 (2002): h. 390-430.

Departemen Pendidikan Nasional RI. Kamus Besar Bahasa Indonesia. Edisi Ketiga. Cet. III; Jakarta: Pusat Bahasa, 2003.

Djamil, Fathurrahman. Filsafat Hukum Islam. Cet. I; Jakarta: Logos Wacana, 1997.

El-Muhtaj, Majdah. Hak Asasi Manusia dalam Konstitusi Indonesia. Cet 4; Jakarta: Kencana, 2012.

Gazali. Al-Mustasfa min al-Ushul. Vol. II. Beirut: Dār al-Kutub al'Ilmiyyah, 1983

Ibn Rusyd. Bidāyah al-Mujtahid wa Nihāyah al-Muqtașid. Cet. 2; Beirut: Dār al-Ma'rifah, 1982.

Ibnu Faris. Mu'jam Maqayis al-Lugah, Juz. 10. Damaskus: Dar al-Fikr, t.th

Ibnu Manzur. Lisan al- 'Arab. Ji;id XI. Kairo: Dar al-Ma'arif, t.th.

Ibrāhīm, Zain al-Dīn. al-Asybāh wa Nazāir. Cet 1; Beirut: Dār al-Fikr, 1983.

. al-Bahru al-Rāiq, Juz 6. Cet 1; Beirut: Dār al-Kutub al'Ilmiyah, 1997.

Jugaym, Nu'mān. Turuq al-Kasyf 'an Maqāṣid al-Syarī'ah, Yordania: Dār al-Nafāis, t.th.

Kementerian Agama RI. Al-Qur'an dan Terjemahnya. Madinah: Majma‘ al-Malik Fahd, 1997.

Mālik bin Anas, al-Muwatta’' Kairo: Dār al-Ḥadis, 1992. . al-Mudawanah al-Kubrā, Juz 4. Kairo: Maṭbu'ah al-Sa'ādah, $1323 \mathrm{H}$.

Mahkamah Konstitusi Republik Indonesia. "Sejarah Pembentukan Mahkamah Konstitusi." Official Website Mahkamah Konstitusi RI. www.mahkamahkonstitusi.go.id/index.php?page $=\quad$ web .profilMK\&ID=1 (29 september 2013).

. "Struktur Organisasi." Official Website Mahkamah 
Konstitusi RI. www.mahkamahkonstitusi.go.id/ 'index. php?page=web.struktur $\quad$ organisasi\&ID $=1 \quad(29$ september 2013). . Putusan MK No 46/PUU-VIII/2010.

Mertokusumo, Sudikno. Hukum Acara Perdata. Yogyakarta: Penerbit Liberty, 1988.

Muhammad, Rusjdi Ali. Hak Asasi Manusia dalam Perspektif Syariat Islam. Cet. I; Banda Aceh: Ar-Raniry Press, 2004.

Perillo, Josep M. "Abuse of Rights: A Pervasive Legal Concept." Pacific Law Jurnal, vol. 27 (1995). http://heinonline .org /HOL/landingPage?

Collection $=$ journal\&handle $=$ hein.journal $/ \mathrm{mclgr} 27 \& \operatorname{div}=14 \& \mathrm{i}$ $\mathrm{d}=$ \&page $=$

Qala'ji, Muḥammad Ruwās. Mu'jam Muștalahạat Ușūl al-Fiqh 'Arabī Injlizị. Damaskus: Dār al-Fikr, 2000.

Republik Indonesia. Undang-undang Dasar 1945.

"Undang-undang R.I. Nomor 8 Tahun 2011 Tentang Perubahan atas Undang-Undang No. 24 Tahun 2003," dalam Undang-Undang Mahkamah Konstitusi. Cet. 1; Jakarta: Sekretariat Jenderal dan Kepaniteraan MKRI, 2011.

. "Undang-undang R.I Nomor 1 Tahun 1974 tentang Perkawinan," dalam Kumpulan Perundang-undangan dalam Lingkungan Peradilan Agama. Cet 4; Jakarta: Yayasan AlHikmah, 1995.

Tanya, Bernard L., Yoan Simanjuntak, dan Markus Hage. Teori Hukum. Cet 4; Yogyakarta: Genta Publishing, 2013.

Zaidān, Abd al-Karìm. al-Wajīz fì Ușūl al-Fiqh. Baghdad: al-Dār alArābiyah li al-Tibā'ah, 1977.

\section{*Dosen PNS Fak. Syariah dan Ekonomi Islam IAIN Palu}

